\title{
Metodologi Feminis: Desain Penelitian Terhadap Perceraian
}

\author{
Oleh :Ulfah Muhayani, MPP.
}

\begin{abstract}
Since its emergence in 1980s, Feminist Research Methodology has become a legitimate, relevant and popular research model. Its quality, and the validity of its findings are beyond contention, and over the years it has produced a significant output that has provided guidelines for policies central to modern society. For its founders and developers, Feminist Research Methodology is designed to study the social conditions of women in a sexist, 'malestream' and patriarchal society. Yet, this methodology is rarely used in studies dealing with women problems in Indonesia. Thus paper aims discuss FMR and its application of the model in divorce studies.
\end{abstract}

\section{A. Pendahuluan}

Sejak kemunculannya di tahun 1980an, Feminist Research Methodology (FMR) menjadi bagian terpenting dalam tradisi penelitian dan ilmu sosial. FMR menjadi metode penelitian emansipatoris yang didesain untuk meneliti permasalahan kondisi sosial perempuan dalam dunia yang sangat sexist, malestream, dan masyarakat yang patriarkhi (Stanley dan Wise, 1993). FMR menjadi metode kritis terhadap tradisi penelitian yang telah ada berpuluh-puluh tahun sebelumnya -tradisi positivist. Namun dalam kemunculannya yang lumayan lama FMR belum mendapatkan tempat dalam penelitian-penelitan sosial di Indonesia khususnya penelitianpenelitian yang berhubungan dengan masalah-masalah perempuan seperti perempuan dan kemiskinan, trafficking (perdangangan manusia), Kekerasan Dalam Rumah Tangga (KDRT), buruh migran perempuan, dan juga penelitian pada kasus perceraian yang marak terjadi di Indonesia belakangan ini. Untuk itu tulisan ini bertujuan untuk mengulas apa itu Feminist Research Methodology dan juga ingin mendesain sebuah bingkai penelitian yang didasarkan pada tradisi feminis untuk penelitian-penelitian tentang perceraian.

\section{B. Perempuan dalam Penelitian-penelitian Sosial di Indonesia}

Ketika pemerintah di bawah kepemimpinan Presiden Susilo Bambang Yudhoyono dan Yusuf Kalla mengumumkan kebijakan pemerintah konversi minyak tanah dan membagikan kompor-kompor dengan bahan bakar elpiji, dengan lantang kedua pasangan pemimpin Republik ini mengumumkan bahwa subsidi pemerintah ini akan diberikan langsung kepada para perempuan atau para ibu. Sontak hal ini membuat para peneliti sosial bersorak gembira karena 
pada akhirnya perempuan diakui keberadaannya dan kemampuannya oleh pengambil kebijakan dalam hal pengelolaan kebutuhan rumah tangga. Mereka (perempuan) tahu apa yang harus dilakukan, demikian argumen yang seringkali dipakai.

Dalam hal lain, kesimpulan yang serupa juga kerap kali disampaikan dengan tanpa analisa yang mendalam bahwa kekerasan dalam rumah tangga tidak akan menjadi masalah karena perempuan-perempuan yang menjadi respondennya menjawab, Tidak ada soal. Itu hak suami.

Kesimpulan sejenis diperlihatkan para peneliti masalah sosial yang mempertanyakan mengapa perempuan aktivis selalu mengatakan dalam krisis ekonomi, pemutusan hubungan kerja (PHK) atas nama efisiensi paling berdampak pada buruh perempuan. Peneliti ini berasumsi bahwa PHK akan dialami baik pekerja laki-laki dan perempuan terus untuk apa kemudian hanya menyebutkan perempuan saja kalau memang keduanya terdampak PHK. Ada hal yang terlupakan oleh para peneliti sosial seperti di atas tersebut yaitu hal yang menjadi perhatian dan perjuangan kaum perempuan dan aktivis perempuan bahwa dalam struktur masyarakat yang patriarkhal ini maka perempuan dan laki-laki akan mempunyai pengalaman yang berbeda satu sama lain, seperti halnya dalam kasus PHK. Kebijakan yang ditujukan kepada perempuan tidak serta merta adalah sebuah kebijakan yang memberikan keuntungan kepada perempuan yang seimbang dengan yang diperoleh oleh laki-laki.

Hal-hal senada juga terjadi dalam penelitian tentang perceraian terutama di Indonesia. Angka perceraian yang sangat tinggi di Indonesia menjadikan isu perceraian menjadi salah satu isu terpenting bagi pemerintah, para praktisi seperti hakim, pengacara ataupun para psikolog, para penasehat perkawinan dan juga para akademisi. Tercatat, pada tahun 2007, sedikitnya 200 ribu pasangan melakukan pisah ranjang alias cerai. Meski angka perceraian di negara ini tidak setinggi di Amerika Serikat dan Inggris (mencapai 66,6\% dan 50\% dari jumlah total perkawinan), namun angka perceraian di Indonesia ini sudah menjadi rekor tertinggi di kawasan Asia Pasifik Tak pelak (suarasurabaya.net). Gejolak yang mengancam kehidupan struktur keluarga ini semakin bertambah jumlahnya pada tiga tahun terakhir ini. Setiap tahun ada 2 juta perkawinan, tetapi yang memilukan perceraian bertambah menjadi dua kali lipat setiap 100 orang yang menikah, 10 pasangan bercerai.

Jumlah angka-angka seperti inilah yang selalu menjadi perhatian utama dalam penelitianpenelitian yang ada. Hal-hal yang sangat penting dan mungkin lebih penting tentang perceraian 
jarang sekali terungkap dalam penelitian-penelitian ini. Hal seperti pengalaman perempuan dan perceraian yang dialami dalam kehidupan mereka jarang sekali menjadi fokus penelitian. Para peneliti dalam bidang ini juga sering dengan cepat menyimpulkan dengan data yang didasarkan pada sumber-sumber seperti laporan-laporan di Pengadilan Agama, kliping-kliping berita koran bahwa penyebab perceraian dikarenakan lifestyle (gaya hidup) masyarakat yang telah berubah dan juga komunikasi yang sudah lama terjalin tidak harmonis antara pasangan suami isteri. Kekerasan dalam rumah tangga jarang sekali muncul ke permukaan sebagai penyebab dari perceraian. Lebih mengejutkan lagi mambaca beberapa analisa dari para pakar bahwa Undangundang KDRT lah yang telah disyahkan oleh DPR di bulan September 2004 menjadi penyebab utama dari keberanian perempuan mengajukan tuntutan cerai kepada suaminya.

Seandainya peneliti itu melakukan analisisnya dengan perspektif feminis, ia tidak akan berhenti pada angka-angka dan tidak akan secepatnya mengambil kesimpulan yang justru merugikan perempuan dan menempatkan perempuan pada posisi yang tidak menyenagkan. Dengan menggunakan metode feminis, peneliti akan mengeksplorasi lebih jauh sehingga dapat memaknai fakta lapangan secara berbeda. Dengan perspektif feminis, suara perempuan terdengar lebih nyaring karena peneliti akan menggugat fakta yang tersodor dengan sejumlah pertanyaan lanjutan dan observasi, disertai empati pada nasib mereka yang dikalahkan dalam suatu relasi kuasa. Karena itu, perspektif ini juga sangat penting untuk menggemakan suara orang-orang dari kelompok yang terpinggir dan dipinggirkan.

Perceraian sudah menjadi permasalahan bagi perempuan. Beban berat yang dipikul perempuan ketika sebuah ikatan pernikahan haruslah terputus. Bagi perempuan perceraian tidak hanya membebani mereka dari segi finansial akan tetapi dari segi emosional perempuan lebih tidak diuntungkan daripada laki-laki atau suami. Bisa kita ambil contoh, banyak kasus perceraian yang diajukan kepada pengadilan oleh para perempuan atau isteri seringkali alasan yang terungkap adalah telah lama tidak terjadi komunikasi yang baik diantara keduanya. Atribut social yang disandang perempuan membuat perempuan yang mengugat cerai seringkali mencari kata untuk memperhalus dan yang lebih bisa diterima oleh masyarakat. Memperhalus fenomena KDRT yang terjadi dengan kata-kata 'tidak ada komunikasi' yang terjalin sejak lama antara suami dan isteri. Ditambah lagi ketika perceraian terjadi perempuan atau salah isteri seringkali disalahkan. Karena masyarakat masih mempunyai anggapan bahwa perempuan dengan segala karakteristik dan sifat-sifat bentukan yang dimiliki sering dibebani tugas sebagai penjaga 
keutuhan rumah tangga. Sehingga ketika perceraian terjadi Isteri atau perempuan seringkali mendapatkan prejudice bahwa ketidakmampuan isterilah yang kemudian menjadi penyebab terjadinya perceraian sebuah hubungan perkawinan.

Angka perceraian yang sangat tinggi di Indonesia memang layak mendapatkan perhatian yang serius dari pemerintah dan juga para akademisi. Namun, sangat disayangkan ketika pengetahuan (knowledge) yang diproduksi dari hasil penelitian tentang perceraian saat ini dijadikan acuan bagi para pengambil kebijakan dan para praktisi bisa dipastikan bahwa kepada sebuah intervensi atau kebijakan yang sesuai dan benar-benar tepat membidik pada permasalahan yang ada.

Penelitian perceraian haruslah didesain dengan lebih teliti dan lebih sensitive terhadap kebutuhan perempuan dan juga laki-laki secara memadai. Penelitian yang diharapkan akan menghasilkan sebuah pengetahuan yang dapat dipakai oleh pemerintah untuk pengambilan kebijakan dan juga para praktisi seperti psikolog dan penasehat pernikahan ketika sebuah solusi yang tepat perlu diambil. FMR adalah sebuah pendekatan penelitian yang menawarkan sebuah pendekatan yang berkemampuan untuk mengungkap hal-hal yang tak tergali oleh tradisi penelitian yang telah ada.

\section{Feminist Research Methodology -Mengungkap yang tak terungkap}

FMR adalah salah satu dari sekian pintu masuk menuju pemahaman produksi pengetahuan feminis beserta kritik dan alternatifnya terhadap praktik-praktik produksi pengetahuan yang sering kali meminggirkan pengalaman perempuan. Karena secara historis, feminisme menentang berlakunya struktur kekuasaan dan asumsi-asumsi antrosentrisme dalam ilmu pengetahuan dan dalam masyarakat. Seperti apa yang dikatakan oleh Miller dan Treitel (1991) bahwa secara umum penelitian feminis adalah tradisi penelitian yang berbeda, tidak sejalan dan juga sebuah kritik terhadap penelitian dan ilmu sosial konvensional. Pengetahuan ilmu sosial yang berkembang saat ini banyak didominasi oleh cara pandang kaum laki-laki yang tercipta dan tertranformasikan oleh para karena memang tidak bisa dipungkiri bahwa cara pandang itu ada karena banyak sekali founding fathers dari ilmu-ilmu sosial adalah laki-laki dan sedikit sekali perempuan. tercipta melalu atau tertranformasikan oleh para ahli yang didominasi oleh laki-laki.

Banyak penulis seperti Harding (1991), Reinharz (1992) telah mengarisbawahi beberapa 
hal dimana praktek-praktek yang sexist terjadi di dalam tardisi keilmuan dan penelitian sosial yang telah ada dan berkembang dalam masyarakat. Bagi Harding dan Reinharz tradisi penelitian yang telah ada sangat didominasi oleh pandangan laki-laki semata -androcentricity. Mereka melihat bahwa dunia ini telah dipersepsikan dan dihadirkan dari kaca mata atau sudut pandang laki-laki saja. Dalam hal ini perempuan hanya dianggap atau dipresentasikan lebih sebagai obyek yang pasif daripada seseorang yang aktif dan bisa mengambil sebuah tindakan. Hal seperti ini bisa menyebabkan dua fenomena yang sangat ekstrim yang disebut sebagai gynopia dimana perempuan sama sekali tak terlihat, dan misogyny, kebencian terhadap perempuan.

Selanjutnya Harding dan Reinharz melihat bahwa tradisi penelitian social seringkali overgeneralisation/overspecificity. Hal ini seringkali terjadi ketika hasil penelitian dari studi dengan specific group digunakan untuk menjelaskan perilaku-perilaku non-specific group atau sebaliknya.

Selain dua hal di atas, tradisi penelitian dan keilmuan sosial konvesional telah dipandang tidak sensitive gender (Gender insensitivity), mempunyai standar ganda (double standards), terlalu berorientasi pada keluarga (familism), dan juga pemisahan secara seksual (sexual dichotomy).

Tradisi penelitian dan keilmuan sosial yang telah ada seringkali tidak sensitive gender. Hal ini terjadi ketika gender sebagai sebuah faktor sama sekali tidak diperhatikan, misalnya, ketika sebuah penelitian ingin melihat efek dari resesi terhadap masyarakat. Penelitian yang tidak memperhatikan factor gender akan menghasilkan penelitian yang bias. Efek resesi tentunya akan berdapak berbeda terhadap laki-laki dan perempuan. Atau ketika sebuah studi tentang pengaruh orang tua terhadapa sosialisasi anak perempuan dalam masyarakat. Nah, ketika tidak dibedakan orang tua ayah atau ibu. Selanjutnya seringkali tradisi tersebut juga mempunya standar ganda atau alat ukur yang berbeda digunakan untuk mengukur isu-isu yang berhubungan dengan lakilaki dan perempuan.

Tradisi penelitian dan keilmuan social konvensional sering kali menekankan keluarga sebagai satu kesatuan ketimbang individu-individu yang ada dalam keluarga tersebut. Jadi seringkali ketika sebuah isu ditujukan kepada keluarga, para inteletual dalam tradisi ini akan menganggap bahwa keseluruhan anggota keluarga suami, isteri dan anak akan terimbas secara sama dan seragam antara satu dengan lainnya. Ditambah lagi bahwa seringkali tradisi penelitian social 
konvensional akan memperhatikan perbedaan jenis kelamin dalam penelitian akan tetapi tidak sampai pada menganalisa hubungan dan relasi gender di dalamnya.

Dengan berbagai kritis yang dilontarkan di atas memang kemudian feminisme merupakan sebuah paradigma alternatif yang dianggap lebih cair, responsif dan tidak dogmatis. Menurut Dominelli (2002), meskipun feminisme berwayuh wajah, teori-teori feminis memiliki beberapa kesamaan dalam hal 1) menjunjung hak azasi wanita untuk terbebas dari penindasan; 2) memberi kesempatan pada wanita berbicara atas nama dirinya dan berdasarkan suaranya sendiri; 3) mendengarkan terhadap apa yang seharusnya dinyatakan oleh wanita; 4) menciptakan gaya hidup alternatif di sini dan saat ini; mengintegrasikan teori dengan praktek; 4) mencari kesesuaian antara tujuan yang ingin dicapai dengan cara-cara pencapaian tujuan itu; 5) memetakan solusi-solusi kolektif yang menghargai individualitas dan keunikan setiap wanita; 6) menghargai kontribusi wanita; dan 7) menggunakan pengalaman-pengalaman wanita secara individu guna memaknakan realitas sosial.

\section{Metode Penelitian dalam Tradisi Feminis}

Hal yang khusus dari penelitian feminis yang membedakan antara tradisi feminis dan tradisi yang sebelumnya adalah metode yang digunakan oleh peneliti feminis dalam penelitian. Reinharz (1992) menawarkan berbagai metode riset dengan berspektif feminis diantaranya:

- Consciousness-raising method atau disebut sebagai metode untuk menimbulkan pengetahuan dan kesadaran

- Group diaries (Diari Kelompok), metode ini

- Dramatic role-play (Permainan peran).

- Geneology and network tracing (Penelusuran jejak dan jejaring)

- Photography or talking technique (Fotografi), teknik pengambilan foto. Metode ini pernah dipakai oleh UNICEF ketika meneliti Pelacuran anak di Indramayu dan Solo. Metode ini digunakan untuk mengungkap tempat-tempat yang dianggap penting oleh para anak-anak yang dilacurkan yang menjadi partisipan dalam penelitian ini. Dengan dibekali sebuah kamera partisipan diajak berkeliling di area penelitian dan diminta untuk memotrek tempat yang mereka anggap penting, tempat yang menakutkan dan tempat yang menyenangkan. 
- Speaking freely into a tape recorder (Berbicara bebas), metode ini bisa dibarengkan dengan metode interview mendalam. Metode ini memberikan kebebasan bagi subyek penelitian mengungkapkan pengalaman mereka. Kedekatan hubungan antara peneliti dan subyek juga sangat dimungkinkan terjalin.

- Answering long, essay-type questionnaires (Menjawab pertanyaan essay).

\section{E. Desain Penelitian untuk Penelitian Perceraian dalam Tradisi Feminis}

Secara lebih mendasar penelitian feminis, mulai dari filsafat ilmunya, proses penelitian dan metode-metode penelitian serta latar belakang asumsi di baliknya merupakan sebuah proses yang secara konstan bergerak di antara konsep dan data, dan juga bergerak secara dinamis antara masyarakat dan fenomena yang ada, antara fenomena di masa lalu dan sekarang dan juga antara hal yang tampak dan yang tak tampak. Riset feminis adalah sebuah metodologi dialektik.

Selanjutnya yang penting dalam penelitian feminis adalah peneliti dan partisipan penelitian. Feminisme telah menekankan pentingnya melibatkan perempuan sebagai peneliti dan partisipasi aktif penelitian (yang dahulunya sering disebut responden). Cerita, perasaan, dan aspirasi responden (subyek penelitian) yang dahulunya cenderung tidak diperhitungkan atau disederhanakan menjadi sekadar angka-angka sesuai dengan intepretasi dan presentasi peneliti, menjadi perhatian yang utama dalam penelitian feminis.

Metode penelitian. Desain penelitian untuk penelitian tentang perceraian selama ini lebih banyak didominasi pendekatan kuantitatif yang berporos pada perspektif positivisme. Teknikteknik pengumpulan data dengan mengunakan kuesioner terstandar (standardized questionnaire), walaupun juga kadang peneliti mengunakan pendekatan kualitatif akan tetapi teknik interview terstruktur. Penelitian feminis menekankan kini penggunaan pendekatan kualitatif yang berporos pada perspektif heuristik dan paskapositivisme (postpositivism). Teknikteknik pengumpulan data yang mengunakan kuesioner terstandar (standardized questionnaires), kini banyak ditinggalkan dan digantikan dengan pedoman wawancara terbuka, observasi terlibat, teknik-teknik partisipasi dan riset aksi.

\section{F. Bingkai Penelitian Perceraian}


Fokus Penelitian. Perlu ditekankan bahwa dalam penelitian feminis pengalamanpengalaman yang dialami perempuan menjadi pusat dari penelitian. Jadi dalam penelitian tentang perceraian dengan menggunakan tradisi feminis, pengalaman perempuan dalam kasus perceraianlah yang dijadikan fokus. Bagi perempuan sebuah perceraian memberikan pengalaman tersendiri dalam hidupnya yang berbeda dengan apa yang dirasakan dan difikirkan oleh seorang laki-laki atau suami. Dunia yang terkonstruksi secara patriarkhi menempatkan posisi perempuan pada posisi yang tidak menguntungkan bagi perempuan ketika terjadi sebuah perceraian. Proses perceraian yang bisanya dibagi menjadi tiga langkah proses sebelum, proses pengadilan, dan paska perceraian. Pengalaman perempuan sebelum gugatan cerai, banyak hal yang menjadi pertimbangan bagi perempuan, status janda yang akan disandangnya kemudian, yang akan memberikan dampak sosial yang seringkali tidak membuat perempuan nyaman, perasaan malu yang timbul karena merasa gagal dalam menyelamatkan perkawinan, memikirkan kehidupan finansial paska perceraian, imbas kepada anak-anak ketika perceraian terjadi. Sebelum proses diajukan oleh baik laki-laki maupun perempuan, pergulatan batin yang dialami oleh pihak isteri dan suami akan sangat berbeda.

Hal-hal yang mungkin diteliti dari sebuah kasus perceraian

- Perceraian, perempuan dan jejaring kapital sosial. Dalam penelitian ini, peneliti dapat menfokuskan pada pengalaman dan jejaring (network) yang dimiliki dan

- Kekerasan dalam rumah tangga dan perceraian.

- Perempuan, Perceraian dan Kemiskinan

- $\quad d l l$

Metode Pengumpulan Data. Hal kedua terpenting dalam penelitian feminis adalah mendesain metode pengumpulan data. Hal ini sangat perlu kehati-hatian karena ada beberapa hal yang perlu diperhatikan seperti, pertama bahwa penelitian feminis benar-benar mengkritisi pendekatan tradisi positivist yang menekankan pada pendekatan quantitative, pendekatan variable-variable dan angka-angka. Untuk itu survey dengan mengunakan pendekatan angkaangka sangat tidak dianjurkan dalam tradisi ini. Namun jika dimungkinkan mengunakan pendekatan quantitative maka pendekatan ini tidaklah menjadi satu-satunya alat untuk menganalisa. Biasanya angka-angka ini akan dilengkapi dengan penjelasan yang bersifat deskriptif yanglebih kaya. Yang kedua adalah, penelitian feminis menentang tradisi positivist 
yang memberikan jarak antara peneliti dan subyek untuk menjaga objektivitas. Positivist berargumen bahwa konsepsi pengetahuan dimana realitas objektif dipercaya berada di luar pengalaman subyektif manusia. Untuk itu bagi positivist jarak antara peneliti dan subyek peneliti haruslah dijaga sejauh mungkin selama proses penelitian berlangsung, meminimalisir kontak untuk menghindari sedapat mungkin respon yang bias karena interpretasi dan pengaruh peneliti (interviewer effect) Sedangkan penelitian feminis menekankan pada kedekatan dan tidak adanya power hierarchy antara peneliti dan subyek penelitian. Jadi metode seperti phone survey, interview, angket sangat jelas tidak dianjurkan untuk digunakan. Yang ketiga adalah tradisi feminis menekankan non-value free studi, menekankan bahwa subyektifitas dalam penelitian dan keenganan terlibat dalam perdebatan validitas penelitian. Keterlibatan dan kedekatan peneliti dan subyek penelitian sangat ditekankan.

Dalam penelitian perceraian metode-metode yang telah disampaikan oleh Reinharz di atas bisa menjadi metode yang ramah terhadap perempuan dan membuat perempuan dapat dengan bebas mengekspresikan pengalaman yang telah dilakoninya. 
Berikut contoh Focus Group Discussion dengan mengunakan diagram Venn yang digunakan untuk mengungkap permasalah perempuan yang ada di masyarakat.

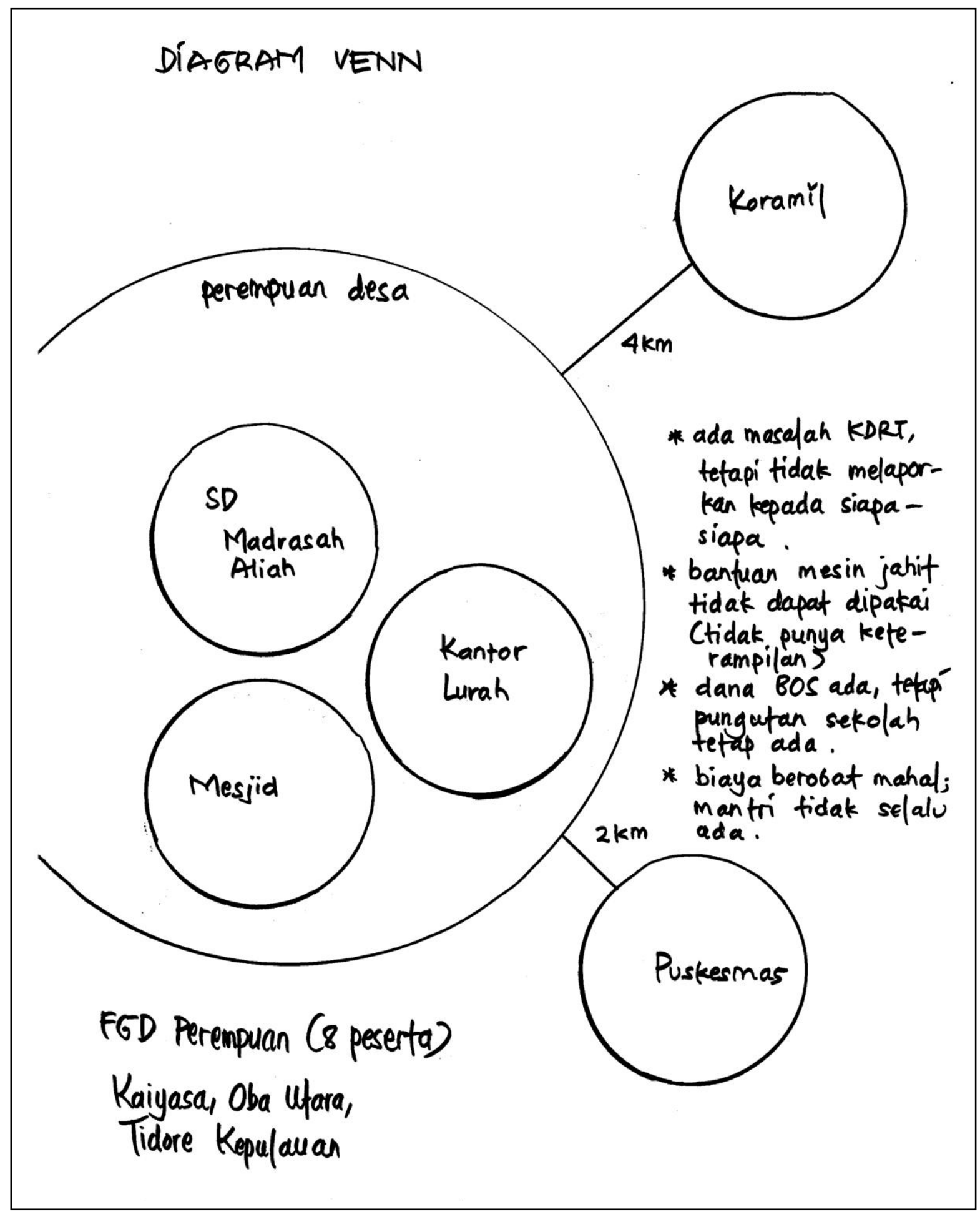

nal

isa

Dat

a.

Ket

elit

ian,

kej

elia

n

dan

kep

eka

an

sert

a

kep

edu

lian

ter

had

ap

isu

per

em

puan dan juga pengetahuan tentang relasi gender dalam Negara, masyarakat dan dalam ruang 
lingkup yang paling kecil yaitu keluarga sangat diperlukan oleh seorang peneliti feminis. Hal ini akan mempengaruhi peneliti dalam menganalisa dan menyajikan hasil penelitian. Memang dalam pandangan feminis, ada beberapa feminis intelektual yang menganggap bahwa ada banyak realitas dalam masyarakat yang dapat diteliti, dan bagi feminis realitas dan pengalaman subyektif dari subyeklah yang harus diutamakan dengan tujuan untuk memberikan kekuasaan dan memperdayakan pengetahuan yang dimiliki oleh subyek penelitian.

Para feminis selanjutnya mendiskusikan validitas dalam tradisi feminis. Bahwa justru validitas penelitian feminis itu adalah dengan cara menghadirkan pengalaman-pengalaman yang kemudian dijadikan pengetahuan dari subyek penelitian dengan tanpa menghadirkan interpretasi peneliti dalam deskripsi pengalaman-pengalaman tersebut. Para feminis juga menekankan bahwa penelitian atau studi yang mempresentasikan hasil data dari pengalaman subyek yang telah diambil dalam framework yang berbeda dari cara pandang subyek melihat dirinya sendiri bukanlah disebut penelitian feminis. Pandangan ini mengindikasikan bahwa para peneliti harus menghormati dan menghargai 'kebenaran' dari perspektif subyek penelitian secara menyeluruh. Para peneliti sebaiknya menarik dari dari meninterpretasikan data-data pengalaman tersebut.

Namun pendapat-pendapat seperti di atas saat ini mulai didiskusikan kembali. Para peniliti feminis saat ini mulai tidak lagi yakin bahwa membiarkan 'pengalaman subyektif' dari subyek penelitian berdiri sendiri tanpa interpretasi dari peniliti feminis. Jadi menurut Montell (1999) dalam bukunya Sprague (2005) 'Feminist Methodologies for Dritical Researchers: Bridging Differences' bahwa jika ingin menguasai suatu isu dalam sebuah penelitian seseorang dituntut untuk mengerti dan memahami secara dalam apa yang menjadi yang sedang dialami dan mempu untuk mengartikulasikan. Untuk itu memerlukan jalinan dialog interpretatif antara peneliti dan subyek penelitian selama proses interview atau dalam proses diskusi. Banyak dari para feminis intelektual juga berpendapat bahwa tanggung jawab mereka tidak hanya berhenti pada melegitimasi pengalaman subyektif dari subyek penelitian, membuat 'visible the invisible', membuat terlihat sesuatu yang tak terlihat, akan tetapi juga mengembangkan analisa-analisa yang diinterpretasikan dan dikontekskan oleh pengalaman-pengalaman yang telah membentuk horizon-horizon manusia, aksi-aksi dan symbol-simbol dalam masyarakat.

Berikut bagaimana para peneliti dalam tradisi feminis menyajikan dan menganalisa data

\section{Cerita perempuan yang mengalami pelecehan seksual di wilayah konflik Maluku}

"Pelakunya dari Satuan Tugas Armed 13 Kontrad. Pelecehan yang dilakukan yaitu dengan cara meremas-remas payudara perempuan. Dari informasi atau cerita yang digali, dapat disampaikan kronologisnya sebagai berikut: saat itu 


\section{G. Beyond Methodology -Isu di luar metodologi}

Tradisi penelitian feminis juga memberikan ciri khusus dalam desain penelitian. Dalam tradisi feminis ada beberapa hal yang perlu diperhatikan oleh para peneliti di luar metodologi penelitian.

\section{Consciousness Raising -Menimbulkan kesadaran}

Ada elemen edukasi yang harus disertakan dalam penelitian feminis baik bagi peneliti dan juga partisipan dalam penelitian. Seringkali kepekaan gender dan isu perempuan belumlah tersosialisasi dengan baik di tengah-tengah masyarakat. Bisa jadi karena Melakukan penelitian terhadap isu-isu perempuan seperti perdagangan orang, pelacuran, kekerasan dalam rumah tangga dan perceraian membutuhkan kepekaaan dan kepedulian terhadap isu dari peneliti. Consciousness Raising (CR) memainkan peranan yang sangat penting di dalam methode feminis sebagai bentuk utama dari penelitian feminis. Dalam prosesnya juga, penelitian haruslah dapat mentransferkan pengetahuan tentang gender kepada subyek penelitian sehingga subyek menjadi terbedayakan. 
Cara untuk menerapkan metode ini adalah melalui penggunaan teknik yang khusus seperti role playing (bermain peran), Pendekatan-pendekatan ini atau metode-metode seperti ini membuat peneliti feminis mudah untuk menggali stock of knowledge dari subyek/perempuan. Dan cara ini pula memberikan peneliti cara dalam proses penelitian untuk mengkomfirmasikan pengalaman-pengalaman perempuan yang dulunya seringkali terlupakan dan terlewatkan (Reinharz, 1992).

\section{Action Orientation-Berorientasi pada Aksi}

Cook dan Fonow (1986) menegaskan bahwa salah satu ciri khusus lain dari studi feminis adalah bereorientasi pada aksi (action orientation). Di dalam siklus proses penelitian feminis, Modus dan analisis feminis melibatkan teori dan praktik. Teori menjadi artikulasi dan pengalaman praktis sehari-hari. Teori juga dilihat sebagai aspek apriori, cara membangun pengetahuan.

Mies (1991) dalam tulisannya mengemukakan bahwa inti dari penelitian feminis adalah perubahan sosial (social change). Penelitian feminis diibaratkan seperti dua mata pisau. Di satu sisi peneliti dalam penelitiannya bertujuan mengungkap pengalaman subyek penelitian, di sisi lain secara bersamaan peneliti juga bertujuan memperdayakan subyek (empowerment) dan membebaskan subyek dari ketertindasan. Maria Mies menambahkan bahwa tujuan dan metode penelitian feminis haruslah sejalan dengan tujuan-tujuan perjuangan perempuan, dan juga sebuah penelitian feminis haruslah terintergasi penuh dalam aksi sosial dan aksi politik untuk pemberdayaan perempuan.

Untuk memahami dan benar-benar mengaplikasikan pendekatan feminis dalam sebuah penelitian, seorang peneliti, menurut Mies, haruslah aktif terlibat dalam perjuangan perempuan.

Dalam konteks penelitian tentang perceraian hal-hal politis yang berhubungan perceraian baik dalam kebijakan dan hukum Negara maupun aturan-aturan dan hukum-hukum agama penting untuk diperhatikan bagi seorang peneliti. Apakah dalam Negara setempat kebijakan perceraian memperlakukan perempuan dan memberikan hak-hak kepada perempuan dengan adil. Apakah ada isu-isu agama yang sensitive terhadap permasalahan perempuan.

\section{H. Antara Peneliti dan Subyek Penelitian -Sebuah Dilema}


Akan tetapi, melakukan penelitian dengan menggunakan pendekatan feminis akan menimbulkan dilema secara etika, politik maupun dalam prakteknya. Penelitian feminis menuntut peneliti untuk terlibat dalam kehidupan subyek yang diteliti secara personal. Hal seperti ini akan sangat memungkinkan menempatkan atau menganggu kehidupan pribadi kehidupan subyek yang kemungkinan besar juga akan merugikan secara material atau non material. Finch (1984) mempertanyakan etika dalam penelitian feminis ketika dia mempertanyakan seberapa besar kontrol peneliti terhadap hal yang ingin diungkap dalam penelitian dan dalam proses penelitian. Keterlibatan peneliti lebih dalam dan intim dengan subyek kemungkinan juga akan menganggu anggota keluarga lainnya jika penelitian ini menyangkut perceraian. Ketidaknyamanan ini bisa jadi menimbulkan reaksi yang negatif dari pihak suami misalnya, anak-anak jika subyek memilikinya atau pihak orang tua. Hal ini selain akan membahayakan subyek juga akan membahayakan peneliti sendiri. Hal ini penting sekali diperhatikan oleh peneliti. 


\section{DAFTAR PUSTAKA}

Cook, Judith \& Mary Margareth Fonow. 1986. 'Knowledge and Women's Interests: Issues of Epistemology and Methodology in Feminist Sociological Research. Sociological Inquiry 56 (1): 2-29.

Dominelli, Lena. 2002. 'Feminist Theory'. In Martin Davies (ed), Companion to Social work. Oxford: Blackwell.

Finch, J. 1984. 'It's Great to Have Someone to Talk to: The Ethics and Politics of Interviewing Women. In C. Bell \& H. Robert (Eds). Social Researching: Politics, Problems, Practice. London: Rouledge \& Keagan Paul.

Harding, S. 1991. Whose Science? Whose Knowledge? New York: Cornell University Press.

Mies, Maria. 1991. 'Women's Research or Feminist Research? The Debate Surrounding Feminist Science and Methodology. In Margaret, J. Fonow \& Judith A. Cook (eds) Beyond Methodology: Feminist Scholarship as Lived Research. Indianapolis: Indiana University Press.

Miller, Connie \& Treitel, Corinna. 1991. Feminist Research Method. Greenwood Press.

Reinharz, Shulamit. 1992. Feminist Methods in Social Research. New Yok: Oxford

Sprague, J. 2005. Feminist Methodologies for Critical Researchers: Bridging Differences. Walnut Creek, CA: altamira Press.

Stanley, L. and Wise, S. (1993) Breaking Out Again: Feminist Ontology and Epistemology. London: Routledge.

Subiyantoro, Eko, B. 2002. 'Perempuan di Wilayah Konflik Maluku: Menakar Hidup di Ladang Bedil’. Jurnal Perempuan. No 24. Jakarta: Yayasan Jurnal Perempuan.

Suarasurabaya.net. 21 September 2007. 'Kajian Wanita DPW PKS Prihatin

Perceraian di Indonesia Tiap Tahun 200 Ribu Pasangan’. www.suarasurabaya.net 